\title{
Spatial and Temporal Abundance of Interacting Populations of White Clover and Grass Species as Assessed by Image Analyses
}

\author{
Anne Kjersti Bakken, ${ }^{1}$ Helge Bonesmo, ${ }^{2}$ and Bård Pedersen ${ }^{3}$ \\ ${ }^{1}$ Norwegian Institute for Agricultural and Environmental Research (Bioforsk), 7512 Stjørdal, Norway \\ ${ }^{2}$ Norwegian Agricultural Economic Research Institute, Statens Hus, P.O. Box 4718, Sluppen, 7468 Trondheim, Norway \\ ${ }^{3}$ Norwegian Institute for Nature Research, P.O. Box 5685, Sluppen, 7485 Trondheim, Norway \\ Correspondence should be addressed to Anne Kjersti Bakken; anne.kjersti.bakken@bioforsk.no
}

Received 2 April 2014; Accepted 26 September 2014

Academic Editor: Nicola Pizzolato

Copyright (C) 2015 Anne Kjersti Bakken et al. This is an open access article distributed under the Creative Commons Attribution License, which permits unrestricted use, distribution, and reproduction in any medium, provided the original work is properly cited.

\begin{abstract}
The dataset comprises detailed mappings of two communities of interacting populations of white clover (Trifolium repens L.) and grass species under differing experimental treatments over 4-5 years. Information from digital photographs acquired two times per season has been processed into gridded data and documents the temporal and spatial dynamics of the species that followed from a wide range of spatial configurations that arose during the study period. The data contribute a unique basis for validation and further development of previously published models for the dynamics and population oscillations in grass-white clover swards. They will be well suited for estimating parameters in spatially explicit versions of these models, like neighborhood based models that incorporate both the dispersal and the local nature of plant-plant interactions.
\end{abstract}

\section{Introduction}

White clover (Trifolium repens L.) is a clonal legume that is commonly grown in grasslands managed for grazing and forage production. The facilitation of long term, stable coexistence of clover and grass in such a system is a challenge [1$4]$ and the community dynamics are still poorly understood. The community has therefore turned out to be an important model system for studying and understanding ecological interactions between plants and the consequences of these interactions for coexistence of populations of different plant species.

Various mechanisms have been proposed to cause population oscillations and formation of clover patches in pastures and swards. Amongst them are facilitation and exploitation [5], balancing local extinction and invasion of clover [6], and synchronous fragmentation of ramets into small and vulnerable individuals [7]. Grass and clover populations are suggested to remain stable at a nitrogen level that balances their competitive advantages; otherwise oscillations are expected $[5,8]$. An increase in nitrogen availability in the sward increases the abundance of grass, and clover is excluded by grass. Time delayed responses to changes in the availability of nitrogen may increase the probability of oscillations [5]. In order to stabilize field scale oscillations of white clover population size, it is suggested that it must have a patchy distribution, be able to invade space where it can achieve high growth rate, and avoid space where it will be outcompeted [9]. In addition, environmental and demographic stochasticity [10] affect dynamics of real ecological systems of interacting species. Such stochastic noise may also induce dynamic phenomena like oscillations, local extinctions, and spatial pattern formation, features that characterize dynamics of grass-clover systems [11, 12].

Thus, both the temporal and spatial variation in clover abundance may be relevant to deduce mechanisms that cause the dynamics. The above theories suggest it is especially relevant to study the spatiotemporal dynamics of clover-grass systems under contrasting environmental conditions that differ with respect to nitrogen availability and disturbance regimes. Simulation models have been developed to explore the spatiotemporal dynamics of white clover populations $[5,6,8,9,13]$. There are, however, few reports from field studies contributing data on spatial dynamics $[6,14-17]$ and 
to the best of our knowledge none that cover temporal and spatial abundance of both grass and clover in contrasting environments.

We have constructed an experiment with swards dominated by white clover and smooth meadow-grass (Poa pratensis ssp. pratensis L.), with different management regimes with respect to cutting frequency and nitrogen supply. The management and treatments were chosen to develop environments that gave differing competitive advantages of grass and clover.

Both the spatial distribution and abundance of white clover and grass were recorded during four or five years by digital photography and image analyses. The results were further processed to gridded data appropriate as inputs to spatial statistical analyses as suggested by Pedersen et al. [18] or simulation models for population dynamics in space and time.

\section{Methodology}

Site description and experimental layout are as follows. The experiment was initiated in 2001 and undertaken at two sites in pastures/leys dominated by white clover and smooth meadow-grass. The first one was located at Mære Agricultural School $\left(63^{\circ} 56^{\prime} \mathrm{N}, 11^{\circ} 25^{\prime} \mathrm{E}, 40 \mathrm{~m}\right.$ a.s.l.) in central Norway in a pasture previously grazed by dairy cattle. The species sown in 1993 besides smooth meadow-grass and white clover were timothy (Phleum pratense L.) and meadow fescue (Festuca pratensis Hudson). In 2001 the timothy and meadow fescue had nearly disappeared and there was a low appearance of weeds. The soil at the site is a sandy loam, and the content of organic matter in the topsoil is $5 \%$.

The second experimental site was located at Kvithamar Research Centre $\left(63^{\circ} 29^{\prime} \mathrm{N} 10^{\circ} 52^{\prime} \mathrm{E}, 40 \mathrm{~m}\right.$ a.s.l.) in a ley sown in spring 2000 with white clover (variety Norstar, Graminor AS, Stange, Norway) and smooth meadow-grass (variety Entopper, Innoseeds b.b., Vlijmen, The Netherlands). Altogether 18 main plots $(4 \mathrm{~m} \times 8 \mathrm{~m}$ each) were split into small plots $(0.5 \mathrm{~m} \times 0.5 \mathrm{~m})$ and sown either with white clover at a rate of $0.8 \mathrm{~g} \mathrm{~m}^{-2}$ or smooth meadow-grass at a rate of $1.7 \mathrm{~g} \mathrm{~m}^{-2}$ or a mixture of both species $\left(0.5 \mathrm{~g} \mathrm{~m}^{-2}+1.5 \mathrm{~g} \mathrm{~m}^{-2}\right)$. The three types of small plots were randomly distributed within main plots and the respective numbers of them in each main plot were 20 with clover, 20 with grass, and 88 with a mixture of the two species. The leys were cut once in late summer 2000 and were not fertilized until spring 2001. The soil at the site is a silt loam (20-25\% clay and 55-65\% silt) and the content of organic matter in the topsoil is $8 \%$.

From spring 2001 until autumn 2004 (Mære)/spring 2005 (Kvithamar), a factorial experiment with two harvesting regimes combined with three nitrogen-fertilizer levels was conducted at both sites. At Mære the treatments were replicated four times on $4 \mathrm{~m} \times 4 \mathrm{~m}$ plots within a total area of $480 \mathrm{~m}^{2}$ and at Kvithamar there were three replicates laid out on $4 \mathrm{~m} \times 8 \mathrm{~m}$ plots within an area of $684 \mathrm{~m}^{2}$. Plots were bordered with $20 \mathrm{~cm}$ wide strips kept free from vegetation by regular spraying with glyphosate. The plots were cut at a stubble height of $5 \mathrm{~cm}$ either two (late June and late August) or four times (late May, late June, late July, and late August) each growing season. The first/second and second/fourth cuts were always synchronised.

Nitrogen was supplied from a compound mineral fertiliser (N-P-K, 18:3:15) at rates of 0,10 , or $30 \mathrm{~g} \mathrm{~m}^{-2} \mathrm{yr}^{-1}$. In the first treatment, $1.5 \mathrm{gP}$ and $5.1 \mathrm{~g} \mathrm{~K} \mathrm{~m}^{-2}$ were supplied from a P-K fertilizer.

In the two-cut regime, $60 \%$ of the fertiliser was distributed in early spring and $40 \%$ after the first cut, whereas in the four-cut regime $40 \%$ was supplied in spring and $20 \%$ after each of the cuts in late May, late June, and late July.

Dry yields were recorded at each of the cuts at Kvithamar. For the years 2002-2005, the content of clover in plotwise subsamples of the yield was determined by Near Infrared Reflectance Spectroscopy [19]. At Mære, there were no yield recordings. On both sites and just before the cuts in late August in 2003 and in late June and August in 2004, the height of the plant canopy was determined by a risingplate meter [20]. There were 128 and 64 recording points within each plot at Kvithamar (Figure 1) and Mære (Figure 2), respectively. Precipitation, temperature, and global radiation for the experimental period are available at Agrometeorology Norway, lmt.bioforsk.no, stations Kvithamar and Mære.

Plots harvested two times per season and supplied with high levels of $\mathrm{N}$ were, by time, invaded by tussock forming and more erect and high yielding grass species than smooth meadow-grass. They were Elytrigia repens L., P. pratense L., Agrostis capillaris L., and Lolium perenne L. After harvest, the initial regrowth rate expressed as plant coverage of soil surface, was slower in such plots. In line with this, bare soil at the time of image acquisition (cf. next section) does not indicate low grass abundance or production.

Determination of plant coverage image acquisition and processing was as follows. To determine the coverage of clover, grass, and dicotyledonous weeds in the experimental fields, they were mapped by means of digital photography about ten days after the cuts in late June and August every year from 2001 and onwards (Figure 3). To ensure that the images were taken at the same positions in the fields at each acquisition, $1.5 \mathrm{~m}$ steel tubes with a diameter of $1.9 \mathrm{~cm}$ were inserted into the ground at the corners of the $4.0 \mathrm{~m} \times 4.0 \mathrm{~m}$ and $4.0 \mathrm{~m} \times 8.0 \mathrm{~m}$ plots. Portable rails were anchored on these tubes on each side of the plot and on the rails, across the plot, a moveable bar was placed, and a sliding $0.5 \mathrm{~m} \times 0.5 \mathrm{~m}$ metal frame that delimited the squares to be analysed sequentially was placed upon the bar (Figure 3).

The area to be photographed was shielded from sunlight by an opaque parasol and the internal blitz of the camera was used to eliminate shadows and ensure even illumination. The camera was mounted to a rack on the metal frame such that the distance from the camera to the ground was kept constant at $80 \mathrm{~cm}$. A digital Olympus Camedia C-3040Zoom camera was used, and the images were stored in a compressed format that gave a spatial resolution of approximately $1600 \times 1600$ pixels $\mathrm{m}^{-2}$.

The information from the digital colour photographs was processed by software (“Trifolium.exe") specially designed for the purpose. The software classifies each pixel in the image as clover, grass, weeds, and bare ground. A thorough description of the image analysis techniques is given by 


\begin{tabular}{|c|c|c|c|c|c|}
\hline 1 & 2 & 3 & 4 & 5 & 6 \\
\hline 7 & 8 & 9 & 10 & 11 & 12 \\
\hline 13 & 14 & 15 & 16 & 17 & 18 \\
\hline
\end{tabular}

(a)

\begin{tabular}{|c|c|c|c|c|c|c|c|}
\hline 1 & 2 & 3 & 4 & 5 & 6 & 7 & 8 \\
\hline 9 & 10 & 11 & 12 & 13 & 14 & 15 & 16 \\
\hline 17 & 18 & 19 & 20 & 21 & 22 & 23 & 24 \\
\hline 25 & 26 & 27 & 28 & 29 & 30 & 31 & 32 \\
\hline 33 & 34 & 35 & 36 & 37 & 38 & 39 & 40 \\
\hline 41 & 42 & 43 & 44 & 45 & 46 & 47 & 48 \\
\hline 49 & 50 & 51 & 52 & 53 & 54 & 55 & 56 \\
\hline 57 & 58 & 59 & 60 & 61 & 62 & 63 & 64 \\
\hline 65 & 66 & 67 & 68 & 69 & 70 & 71 & 72 \\
\hline 73 & 74 & 75 & 76 & 77 & 78 & 79 & 80 \\
\hline 81 & 82 & 83 & 84 & 85 & 86 & 87 & 88 \\
\hline 89 & 90 & 91 & 92 & 93 & 94 & 95 & 96 \\
\hline 97 & 98 & 99 & 100 & 101 & 102 & 103 & 104 \\
\hline 105 & 106 & 107 & 108 & 109 & 110 & 111 & 112 \\
\hline 113 & 114 & 115 & 116 & 117 & 118 & 119 & 120 \\
\hline 121 & 122 & 123 & 124 & 125 & 126 & 127 & 128 \\
\hline
\end{tabular}

(b)

FIGURE 1: Orientation of the maps at Kvithamar: (a) 18 plots $(4 \mathrm{~m} \times$ $8 \mathrm{~m}$ plots each) and (b) 128 subplots (small plots: $0.5 \mathrm{~m} \times 0.5 \mathrm{~m}$ plots each).

Bonesmo et al. [21]. The $0.5 \mathrm{~m} \times 0.5 \mathrm{~m}$ single images were after processing by the software (Figure 4 ) combined into one picture (TIF-format) (Figure 5) or data file for each plot after identifying overlap zones and removing them from one of the overlapping images. The procedure for removing overlap zones as well as the software Trifolium.exe is available from the authors. The copyright for the source code of Trifolium.exe is not owned by the authors and cannot be published here.

\section{Dataset Description}

The dataset associated with this Dataset Paper consists of 21 items which are described as follows.

Dataset Item 1 (Images). Photos for each plot and image acquisition at Kvithamar. All photos together covered the whole plot. The photos are named according to the number

\begin{tabular}{|c|c|c|c|c|c|c|c|}
\hline 8 & 7 & 6 & 5 & 4 & 3 & 2 & 1 \\
\hline 16 & 15 & 14 & 13 & 12 & 11 & 10 & 9 \\
\hline 24 & 23 & 22 & 21 & 20 & 19 & 18 & 17 \\
\hline
\end{tabular}

(a)

\begin{tabular}{|c|c|c|c|c|c|c|c|}
\hline 1 & 2 & 3 & 4 & 5 & 6 & 7 & 8 \\
\hline 9 & 10 & 11 & 12 & 13 & 14 & 15 & 16 \\
\hline 17 & 18 & 19 & 20 & 21 & 22 & 23 & 24 \\
\hline 25 & 26 & 27 & 28 & 29 & 30 & 31 & 32 \\
\hline 33 & 34 & 35 & 36 & 37 & 38 & 39 & 40 \\
\hline 41 & 42 & 43 & 44 & 45 & 46 & 47 & 48 \\
\hline 49 & 50 & 51 & 52 & 53 & 54 & 55 & 56 \\
\hline 57 & 58 & 59 & 60 & 61 & 62 & 63 & 64 \\
\hline
\end{tabular}

(b)

FIgURE 2: Orientation of the maps at Mære: (a) 24 plots $(4 \mathrm{~m} \times$ $4 \mathrm{~m}$ plots each) and (b) 64 subplots (small plots: $0.5 \mathrm{~m} \times 0.5 \mathrm{~m}$ plots each).

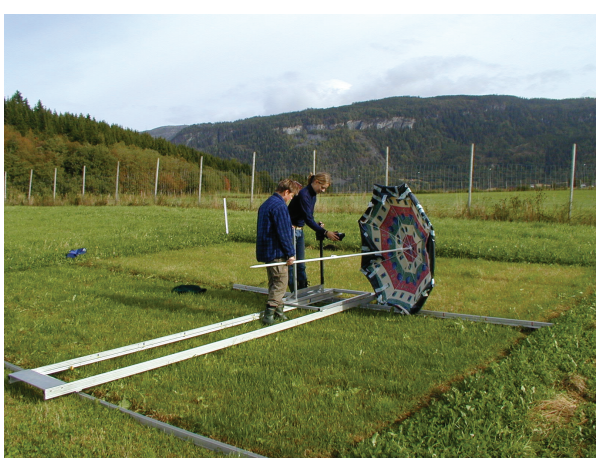

FIgURE 3: Positioned image acquisition to map the grass-clover sward.

of image acquisition (9 image acquisitions), plot number (18 main plots), and subplot number (128 subplots). These photos were the basis for the image analyses conducted by the software Trifolium.exe. There are altogether 20736 photos (9 image acquisitions $\times 18$ plots/acquisition $\times 128$ photos/plot). A few photographs are missing.

Dataset Item 2 (Images). Photos for each plot and image acquisition at Mære. All photos together covered the whole plot. The photos are named according to the number of image acquisition (8 image acquisitions), plot number (24 main plots), and subplot number (64 subplots). These photos were the basis for the image analyses conducted by the software Trifolium.exe. There are altogether 12288 photos (8 image acquisitions $\times 24$ plots/acquisition $\times 64$ photos/plot). A few photographs are missing. 


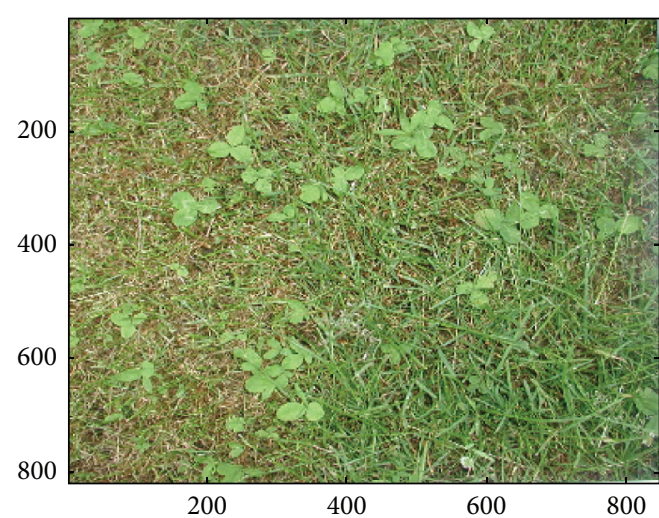

(a) Image

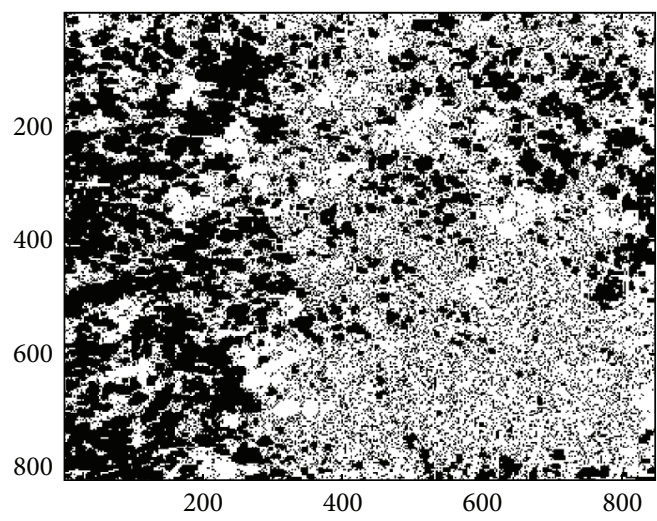

(c) Edge image

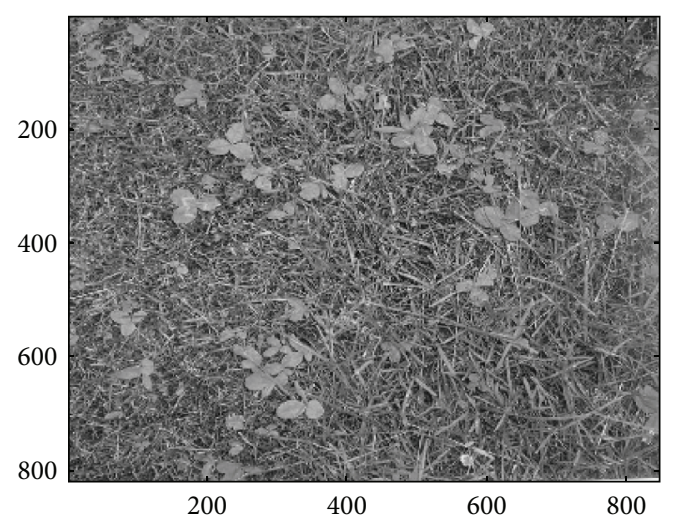

(b) Grey level image

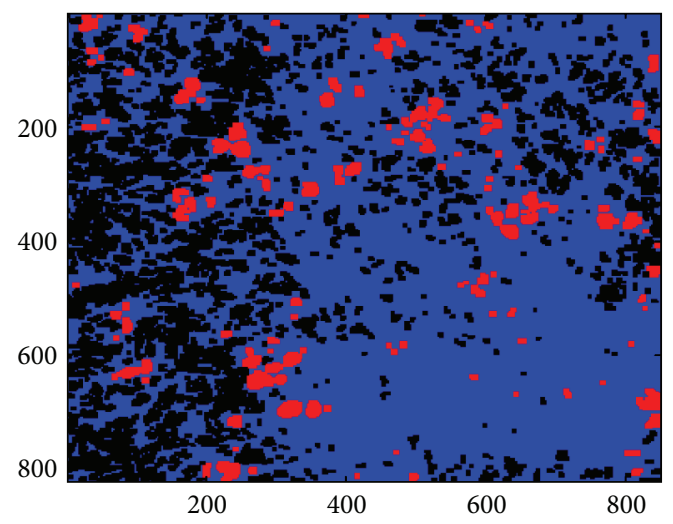

(d) Classification

FIGURE 4: Outputs at sequential steps in the analysis of (a) a digital colour image by the software Trifolium.exe, (b) grey level image, (c) edge image, and (d) classified image, where red indicates clover, blue indicates grass, and black indicates soil (published with permission from Taylor \& Francis Group, and previously printed in [21]).

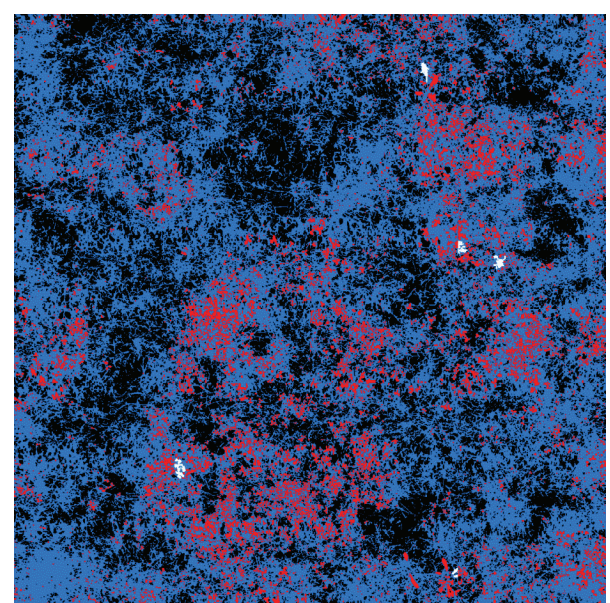

Figure 5: An example of a $4 \mathrm{~m} \times 4 \mathrm{~m}$ plot with patterns occurring from identification of pixels either as clover (red), grass (blue), bare ground (black), or dicotyledonous weeds (white).

Dataset Item 3 (Table). Treatments allocated to the different plots are listed together with harvest dates, data for harvested yield, and clover proportion in dried yield samples, as determined by NIRS. Yields were recorded at the site Kvithamar only. The column Site identifies whether the site is Kvithamar or Mære. The column Plot Number presents the plot number within site (1-18 at Kvithamar and 1-24 at Mære). In the column Harvesting Regime, 1 indicates two cuts per season and 2 indicates four cuts per season. In the column Nitrogen Supply Rate, 1 indicates $0 \mathrm{~g}, 2$ indicates $10 \mathrm{~g}$, and 3 indicates $30 \mathrm{~g}$. The column Yield One presents the dry matter yield $\left(\mathrm{g} \mathrm{m}^{-2}\right)$ at harvest in spring (May/June); Yield Two, the dry matter yield $\left(\mathrm{g} \mathrm{m}^{-2}\right)$ at harvest in early summer (June/July); Yield Three, the dry matter yield $\left(\mathrm{g} \mathrm{m}^{-2}\right)$ at harvest in late summer (July/August); Yield Four, the dry matter yield $\left(\mathrm{g} \mathrm{m}^{-2}\right)$ at harvest in autumn (August/September). The column Clover One presents the proportion (\%, weight/weight) of clover in yields in spring; Clover Two, the proportion (\%, weight/weight) of clover in yields in early summer; Clover Three, the proportion (\%, weight/weight) of clover in yields in late summer; Clover Four, the proportion (\%, weight/weight) of clover in yields in autumn. The column Date One presents the date of harvest in spring; Date Two, the date of harvest in early summer; Date Three, the date of harvest in late summer; Date Four, the date of harvest in autumn. The harvest dates at Mære were 2-3 days later than respective dates at Kvithamar. A dot (.) in a 
cell indicates that no value was recorded for this combination of harvesting regime, $\mathrm{N}$-supply rate, year, and time of season.

Column 1: Site
Column 2: Plot Number
Column 3: Harvesting Regime
Column 4: Nitrogen Supply Rate $\left(\mathrm{g} \mathrm{m}^{-2} \mathrm{y}^{-1}\right)$
Column 5: Year
Column 6: Yield One $\left(\mathrm{g} \mathrm{m}^{-2}\right)$
Column 7: Yield Two $\left(\mathrm{g} \mathrm{m}^{-2}\right)$
Column 8: Yield Three $\left(\mathrm{g} \mathrm{m}^{-2}\right)$
Column 9: Yield Four $\left(\mathrm{g} \mathrm{m}^{-2}\right)$
Column 10: Clover One $(\%)$
Column 11: Clover Two $(\%)$
Column 12: Clover Three $(\%)$
Column 13: Clover Four $(\%)$
Column 14: Date One
Column 15: Date Two
Column 16: Date Three
Column 17: Date Four

Dataset Item 4 (Matrices). Registration of the first image acquisition at Kvithamar containing 18 matrices that contain $2400 \times 1200$ cells describing the $8 \mathrm{~m} \times 4 \mathrm{~m}$ plots. Each cell in the matrices contains one digit $(1,2,3$, or 4$)$, which identifies the character of single cells as being covered by clover (1), grass (2), bare ground (3), or dicotyledonous weeds (4). For a few plots, there are smaller areas that are not identified. Such cells are annotated with the digit 0 .

Dataset Item 5 (Matrices). Registration of the second image acquisition at Kvithamar containing 18 matrices that contain $2400 \times 1200$ cells describing the $8 \mathrm{~m} \times 4 \mathrm{~m}$ plots. Each cell in the matrices contains one digit $(1,2,3$, or 4$)$, which identifies the character of single cells as being covered by clover (1), grass (2), bare ground (3), or dicotyledonous weeds (4). For a few plots, there are smaller areas that are not identified. Such cells are annotated with the digit 0 .

Dataset Item 6 (Matrices). Registration of the third image acquisition at Kvithamar containing 18 matrices that contain $2400 \times 1200$ cells describing the $8 \mathrm{~m} \times 4 \mathrm{~m}$ plots. Each cell in the matrices contains one digit $(1,2,3$, or 4$)$, which identifies the character of single cells as being covered by clover (1), grass (2), bare ground (3), or dicotyledonous weeds (4). For a few plots, there are smaller areas that are not identified. Such cells are annotated with the digit 0 .

Dataset Item 7 (Matrices). Registration of the fourth image acquisition at Kvithamar containing 18 matrices plots that contain $2400 \times 1200$ cells describing the $8 \mathrm{~m} \times 4 \mathrm{~m}$. Each cell in the matrices contains one digit $(1,2,3$, or 4$)$, which identifies the character of single cells as being covered by clover (1), grass (2), bare ground (3), or dicotyledonous weeds (4). For a few plots, there are smaller areas that are not identified. Such cells are annotated with the digit 0 .

Dataset Item 8 (Matrices). Registration of the fifth image acquisition at Kvithamar containing 18 matrices that contain $2400 \times 1200$ cells describing the $8 \mathrm{~m} \times 4 \mathrm{~m}$ plots. Each cell in the matrices contains one digit $(1,2,3$, or 4$)$, which identifies the character of single cells as being covered by clover (1), grass (2), bare ground (3), or dicotyledonous weeds (4). For a few plots, there are smaller areas that are not identified. Such cells are annotated with the digit 0 .

Dataset Item 9 (Matrices). Registration of the sixth image acquisition at Kvithamar containing 18 matrices that contain $2400 \times 1200$ cells describing the $8 \mathrm{~m} \times 4 \mathrm{~m}$ plots. Each cell in the matrices contains one digit $(1,2,3$, or 4$)$, which identifies the character of single cells as being covered by clover (1), grass (2), bare ground (3), or dicotyledonous weeds (4). For a few plots, there are smaller areas that are not identified. Such cells are annotated with the digit 0 .

Dataset Item 10 (Matrices). Registration of the seventh image acquisition at Kvithamar containing 18 matrices that contain $2400 \times 1200$ cells describing the $8 \mathrm{~m} \times 4 \mathrm{~m}$ plots (plot 9 is missing). Each cell in the matrices contains one digit (1, 2,3 , or 4 ), which identifies the character of single cells as being covered by clover (1), grass (2), bare ground (3), or dicotyledonous weeds (4). For a few plots, there are smaller areas that are not identified. Such cells are annotated with the digit 0 .

Dataset Item 11 (Matrices). Registration of the eighth image acquisition at Kvithamar containing 18 matrices that contain $2400 \times 1200$ cells describing the $8 \mathrm{~m} \times 4 \mathrm{~m}$ plots (plot 8 is missing). Each cell in the matrices contains one digit (1, 2,3 , or 4 ), which identifies the character of single cells as being covered by clover (1), grass (2), bare ground (3), or dicotyledonous weeds (4). For a few plots, there are smaller areas that are not identified. Such cells are annotated with the digit 0 .

Dataset Item 12 (Matrices). Registration of the ninth image acquisition at Kvithamar containing 18 matrices that contain $2400 \times 1200$ cells describing the $8 \mathrm{~m} \times 4 \mathrm{~m}$ plots. Each cell in the matrices contains one digit $(1,2,3$, or 4$)$, which identifies the character of single cells as being covered by clover (1), grass (2), bare ground (3), or dicotyledonous weeds (4). For a few plots, there are smaller areas that are not identified. Such cells are annotated with the digit 0 .

Dataset Item 13 (Matrices). Registration of the first image acquisition at Mære containing 24 matrices that contain $1200 \times 1200$ cells describing the $4 \mathrm{~m} \times 4 \mathrm{~m}$ plots. Each cell in the matrices contains one digit $(1,2,3$, or 4$)$, which identifies the character of single cells as being covered by clover (1), grass (2), bare ground (3), or dicotyledonous weeds (4). For a 
few plots, there are smaller areas that are not identified. Such cells are annotated with the digit 0 .

Dataset Item 14 (Matrices). Registration of the second image acquisition at Mære containing 24 matrices that contain $1200 \times 1200$ cells describing the $4 \mathrm{~m} \times 4 \mathrm{~m}$ plots (plots 11,19 , and 20 are missing). Each cell in the matrices contains one digit $(1,2,3$, or 4$)$, which identifies the character of single cells as being covered by clover (1), grass (2), bare ground (3), or dicotyledonous weeds (4). For a few plots, there are smaller areas that are not identified. Such cells are annotated with the digit 0 .

Dataset Item 15 (Matrices). Registration of the third image acquisition at Mære containing 24 matrices that contain $1200 \times 1200$ cells describing the $4 \mathrm{~m} \times 4 \mathrm{~m}$ plots. Each cell in the matrices contains one digit $(1,2,3$, or 4$)$, which identifies the character of single cells as being covered by clover (1), grass (2), bare ground (3), or dicotyledonous weeds (4). For a few plots, there are smaller areas that are not identified. Such cells are annotated with the digit 0 .

Dataset Item 16 (Matrices). Registration of the fourth image acquisition at Mære containing 24 matrices that contain $1200 \times 1200$ cells describing the $4 \mathrm{~m} \times 4 \mathrm{~m}$ plots. Each cell in the matrices contains one digit $(1,2,3$, or 4$)$, which identifies the character of single cells as being covered by clover (1), grass (2), bare ground (3), or dicotyledonous weeds (4). For a few plots, there are smaller areas that are not identified. Such cells are annotated with the digit 0 .

Dataset Item 17 (Matrices). Registration of the fifth image acquisition at Mære containing 24 matrices that contain $1200 \times 1200$ cells describing the $4 \mathrm{~m} \times 4 \mathrm{~m}$ plots. Each cell in the matrices contains one digit $(1,2,3$, or 4$)$, which identifies the character of single cells as being covered by clover (1), grass (2), bare ground (3), or dicotyledonous weeds (4). For a few plots, there are smaller areas that are not identified. Such cells are annotated with the digit 0 .

Dataset Item 18 (Matrices). Registration of the sixth image acquisition at Mære containing 24 matrices that contain $1200 \times 1200$ cells describing the $4 \mathrm{~m} \times 4 \mathrm{~m}$ plots. Each cell in the matrices contains one digit $(1,2,3$, or 4$)$, which identifies the character of single cells as being covered by clover (1), grass (2), bare ground (3), or dicotyledonous weeds (4). For a few plots, there are smaller areas that are not identified. Such cells are annotated with the digit 0 .

Dataset Item 19 (Matrices). Registration of the seventh image acquisition at Mære containing 24 matrices that contain $1200 \times 1200$ cells describing the $4 \mathrm{~m} \times 4 \mathrm{~m}$ plots. Each cell in the matrices contains one digit $(1,2,3$, or 4$)$, which identifies the character of single cells as being covered by clover (1), grass (2), bare ground (3), or dicotyledonous weeds (4). For a few plots, there are smaller areas that are not identified. Such cells are annotated with the digit 0 .
Dataset Item 20 (Matrices). Registration of the eighth image acquisition at Mære containing 24 matrices that contain $1200 \times 1200$ cells describing the $4 \mathrm{~m} \times 4 \mathrm{~m}$ plots. Each cell in the matrices contains one digit $(1,2,3$, or 4$)$, which identifies the character of single cells as being covered by clover (1), grass (2), bare ground (3), or dicotyledonous weeds (4). For a few plots, there are smaller areas that are not identified. Such cells are annotated with the digit 0 .

Dataset Item 21 (Table). Recordings of plant canopy height at Kvithamar and Mære in late August in 2003, late June in 2004, and late August in 2004. There were 128 and 64 recording points within each plot at Kvithamar and Mære, respectively.

Column 1: Cut Date

Column 2: Site

Column 3: Plot Number

Column 4: Subplot Number

Column 5: Height (cm)

\section{Concluding Remarks}

The dataset presented here will contribute a unique basis for validation and further development of previously published models for the dynamics and population oscillations in grasswhite clover swards. The set documents the spatial dynamics of the two species that followed from a wide range of spatial configurations that arose during the experiment. It should therefore be well suited for estimating parameters in spatially explicit versions of these models, like neighborhood based models that incorporate both the dispersal and the local nature of plant-plant interactions (e.g., [22-25]). For example, the hypothesis that a patchy distribution of clover and its ability to invade space where it is not outcompeted will damp oscillations may be tested.

\section{Dataset Availability}

The dataset associated with this Dataset Paper is dedicated to the public domain using the CCO waiver and is available at http://dx.doi.org/10.1155/2015/620164/dataset.

\section{Conflict of Interests}

There is no conflict of interests in the access or publication of this dataset.

\section{Acknowledgments}

Anne Stine Ekker and Anne Langerud have contributed substantially to this work. The Norwegian Research Council and Bioforsk are acknowledged for financial support.

\section{References}

[1] K. W. Steele and P. Shannon, "Concepts relation to the nitrogen economy of a Northland intensive beef farm," in Nitrogen 
Balances in New Zealand Ecosystems, P. Gandar, Ed., pp. 85-89, Department of Scientific and Industrial Research, Wellington, New Zealand, 1982.

[2] M. G. Lambert, D. A. Clark, D. A. Grant, and D. A. Costall, "Influence of fertiliser and grazing management on North Island moist hill country. 2. Pasture botanical composition.", New Zealand Journal of Agricultural Research, vol. 29, no. 1, pp. 1-10, 1986.

[3] D. S. Rickard and S. D. McBride, "Irrigated and nonirrigated pasture production at Winchmore," Tech. Rep. 21, Winchmore Irrigation Research Station, 1986.

[4] D. A. Davies, M. Fothergill, and C. T. Morgan, "Assessment of contrasting perennial ryegrasses, with and without white clover, under continuous sheep stocking in the uplands. 5. Herbage production, quality and intake in years 4-6," Grass \& Forage Science, vol. 48, no. 3, pp. 213-222, 1993.

[5] S. Schwinning and A. J. Parsons, "Analysis of the coexistence mechanisms for grasses and legumes in grazing systems," Journal of Ecology, vol. 84, no. 6, pp. 799-813, 1996.

[6] M. L. Cain, S. W. Pacala, J. A. Silander Jr., and M.-J. Fortin, "Neighborhood models of clonal growth in the white clover Trifolium repens," The American Naturalist, vol. 145, no. 6, pp. 888-917, 1995.

[7] M. Fothergill, D. A. Davies, and G. J. Daniel, "Morphological dynamics and seedling recruitment in young swards of three contrasting cultivars of white clover (Trifolium repens) under continuous stocking with sheep," Journal of Agricultural Science, vol. 128, no. 2, pp. 163-172, 1997.

[8] J. H. M. Thornley, J. Bergelson, and A. J. Parsons, "Complex dynamics in a carbon-nitrogen model of a grass-legume pasture," Annals of Botany, vol. 75, no. 1, pp. 79-94, 1995.

[9] S. Schwinning and A. J. Parsons, "A spatially explicit population model of stoloniferous $\mathrm{N}$-fixing legumes in mixed pasture with grass," Journal of Ecology, vol. 84, no. 6, pp. 815-826, 1996.

[10] R. Lande, S. Engen, and B.-E. Sæther, Stochastic Population Dynamics in Ecology and Conservation, Oxford University Press, Oxford, UK, 2003.

[11] B. Spagnolo, A. Fiasconaro, and D. Valenti, "Noise induced phenomena in Lotka-Volterra systems," Fluctuation and Noise Letters, vol. 3, no. 2, pp. L177-L185, 2003.

[12] B. Spagnolo, D. Valenti, and A. Fiasconaro, "Noise in ecosystems: a short review," Mathematical Biosciences and Engineering, vol. 1, no. 1, pp. 185-211, 2004.

[13] J. M. Sharp, G. R. Edwards, and M. J. Jeger, "A spatially explicit population model of the effect of spatial scale of heterogeneity in grass-clover grazing systems," The Journal of Agricultural Science, vol. 152, no. 3, pp. 394-407, 2014.

[14] C. A. Marriott, M. A. Smith, and M. A. Baird, "The effect of urine on clover performance in a grazed upland sward," The Journal of Agricultural Science, vol. 109, no. 1, pp. 177-185, 1987.

[15] T. E. Thorhallsdottir, "The dynamics of a grassland community: a simultaneous investigation of spatial and temporal heterogeneity at various scales," Journal of Ecology, vol. 78, no. 4, pp. 884-908, 1990.

[16] G. R. Edwards, A. J. Parsons, J. A. Newman, and I. A. Wright, "The spatial pattern of vegetation in cut and grazed grass/white clover pastures," Grass and Forage Science, vol. 51, no. 3, pp. 219231, 1996.

[17] R. Thanopoulos, C. A. Marriott, and N. Sidiras, "Dynamics of perennial ryegrass and white clover in sown swards in NW Greece," Grass and Forage Science, vol. 55, no. 4, pp. 361-366, 2000.
[18] B. Pedersen, H. Bonesmo, and A. K. Bakken, "Analysing white clover patchiness by wavelets and quadrat variance methods," in Adaption and Management of Forage Legumes-Strategies for Improved Reliability in Mixed Swards, B. E. Frankow-Lindberg, R. P. Collins, A. Lüscher, M. T. Sébastia, and Á. Helgadóttir, Eds., Proceedings of the 1st COST 852 workshop held in Ystad, Sweden 20-22 September, pp. 286-289, Department of Ecology and Crop Production Science, Swedish University of Agricultural Sciences, 2004.

[19] G. Fystro and T. Lunnan, "Analysar av grovfôrkvalitet på NIRS," Bioforsk Fokus, vol. 1, no. 3, pp. 180-181, 2006.

[20] F. L. Mould, "Use of a modified rising-plate meter to assess changes in sward height and structure," Norwegian Journal of Agricultural Sciences, vol. 6, no. 4, pp. 375-382, 1992.

[21] H. Bonesmo, K. Kaspersen, and A. K. Bakken, "Evaluating an image analysis system for mapping white clover pastures," Acta Agriculturae Scandinavica B: Soil and Plant Science, vol. 54, no. 2, pp. 76-82, 2004.

[22] B. Bolker and S. W. Pacala, "Using moment equations to understand stochastically driven spatial pattern formation in ecological systems," Theoretical Population Biology, vol. 52, no. 3, pp. 179-197, 1997.

[23] B. M. Bolker, S. W. Pacala, and S. A. Levin, "Moment methods for ecological processes in continuous space," in The Geometry of Ecological Interactions: Simplifying Spatial Complexity, U. Dieckmann, R. Law, and J. A. J. Metz, Eds., pp. 388-411, Cambridge University Press, Cambridge, UK, 2000.

[24] Y. Iwasa, "Lattice models and pair approximation in ecology," in The Geometry of Ecological Interactions: Simplifying Spatial Complexity, U. Dieckmann, R. Law, and J. A. J. Metz, Eds., pp. 227-251, Cambridge University Press, Cambridge, UK, 2000.

[25] R. Law and U. Dieckmann, "Moment approximations of individual-based models," in The Geometry of Ecological Interactions: Simplifying Spatial Complexity, U. Dieckmann, R. Law, and J. A. J. Metz, Eds., pp. 252-270, Cambridge University Press, Cambridge, UK, 2000. 

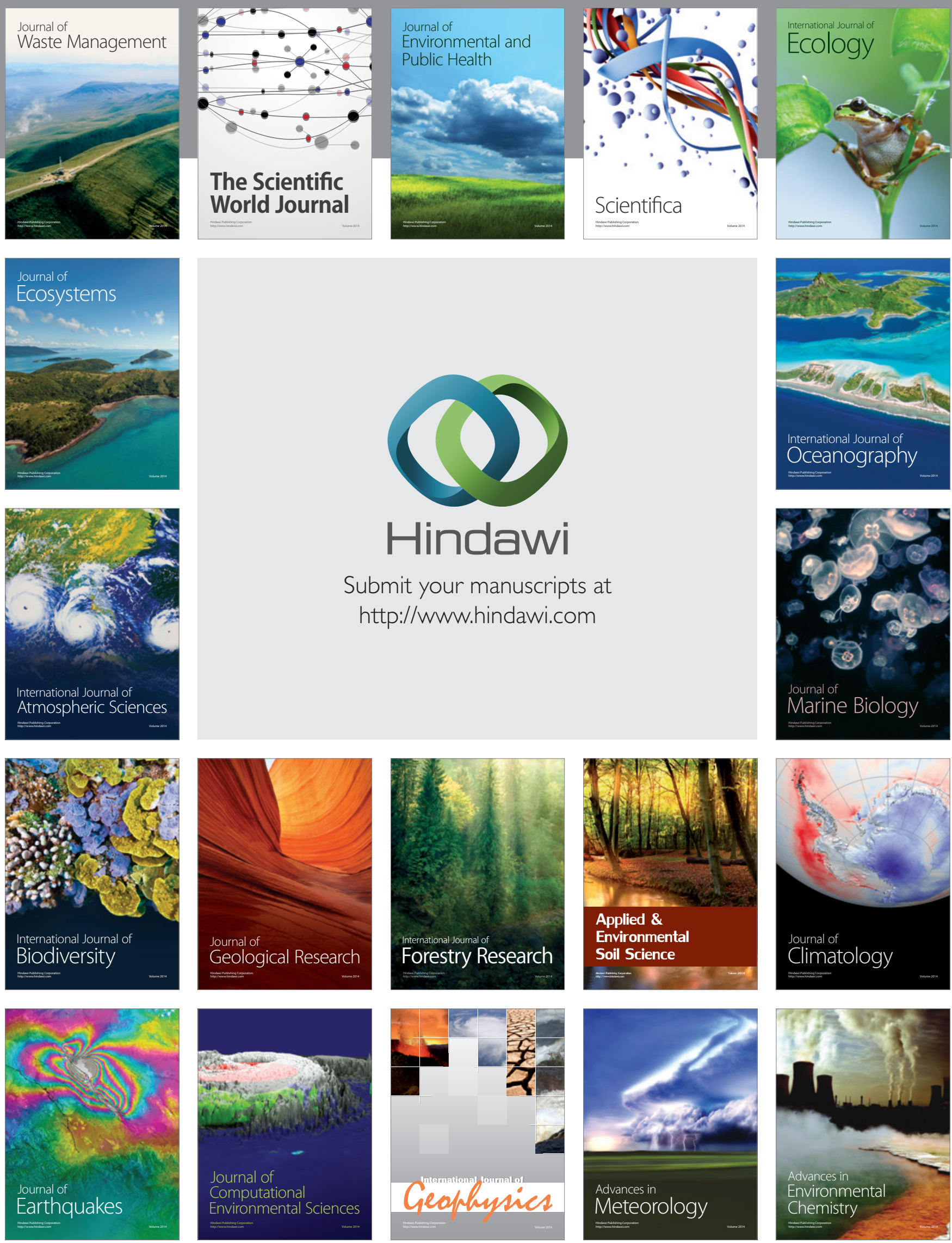